\title{
ZINC - ROOTING COFACTOR IN RUBBER TREE MINI-CUTTINGS
}

\section{ZINCO - COFATOR DE ENRAIZAMENTO EM MINIESTACAS DE SERINGUEIRA}

\author{
Joelmir Vital da SILVA ${ }^{\mathbf{1}}$; Wilson Itamar MARUYAMA ${ }^{\mathbf{1}}$; \\ Carlos Eduardo da Silva OLIVEIRA'; Fábio STEINER ${ }^{1}$; Alan Mario ZUFFO² ${ }^{\text {; Tiago ZOZ }}{ }^{\mathbf{1}}$ \\ 1. Universidade Estadual de Mato Grosso do Sul, Programa de Pós-Graduação em Agronomia, Cassilândia, MS, Brazil; 2. Curso de \\ Agronomia, Universidade Federal de Mato Grosso do Sul, Chapadão do Sul, MS, Brazil. steiner@uems.br
}

\begin{abstract}
The rubber tree (Hevea brasiliensis Müell. Arg.) is a species of significant economic interest in the natural rubber industry in Brazil and the world. This species presents recalcitrance to rooting, and its cuttings are difficult to propagate. This study aimed to evaluate the effect of the pre-conditioning of rubber tree mini-cuttings with zinc on the improvement of the adventitious rooting of rootstocks. Mini-cuttings were standardized with $45 \mathrm{~mm}$ length and submitted to preconditioning by immersion of the mini-cutting base in solutions containing $0.00 ; 0.04 ; 0.08 ; 0.16 ; 0.32$ and $0.64 \mathrm{mg} \mathrm{L}^{-1}$ of $\mathrm{Zn}$, for 24 hours. The experimental design was randomized blocks with six treatments and four replicates of 10 mini-cuttings. The rubber tree minicuttings were placed in a fitotron-type growth chamber, at $25^{\circ} \mathrm{C}$, with 12-hour photoperiod, $5,000 \mathrm{~K}$ intensity, and $95 \%$ of relative air humidity, for 60 days. The survival rate, number of buds, percentage of mini-cuttings that had leaf abscission, the percentage of mini-cuttings with callogenesis in the root meristem, the percentage of rooted mini-cuttings, the number of primary roots and root length were evaluated. The highest values of survival rate, the number of buds, the number of primary roots, the percentage of mini-cuttings with callogenesis in the root meristem, the percentage of rooted mini-cuttings and root length were observed with 0.16 to $0.26 \mathrm{Mg} \mathrm{L}^{-1}$ of $\mathrm{Zn}$. The use of zinc in the mini-cuttings of rubber tree reduces linearly the percentage of mini-cuttings that had leaf abscission and the formation of callogenesis in the root meristem.
\end{abstract} propagation.

KEYWORDS: Cloning. Hevea brasiliensis. Mini-cutting technique. Root induction. Vegetative

\section{INTRODUCTION}

Rubber tree, which is originally from the Amazon region, belongs to the Euphorbiaceae family, stands out as the world's leading source of natural rubber, and the latex extraction has become crucial for developed countries (ALVARENGA; CARMO, 2014). In the last decades, the increase of the world population raised the demand for natural rubber (latex), that is a renewable source (GONÇALVES et al., 2002).

In Brazil, the rubber tree has been grown in the Southeast, Midwest, and Bahia state (ALVARENGA; CARMO, 2014). Given this favorable scenario for the production chain of this species, it is necessary to looking for new techniques to get quality seedlings, which will improve the growth and development of the plants in the field and, consequently, increase the production of natural rubber sustainably and economically.

The seedlings used for commercial purposes are mostly produced using rootstock (ALVARENGA; CARMO, 2014), which is obtained using seeds. However, rootstocks from unselected seeds result in less vigor and less growth and development of the grafts (MARTINS et al.,
2000), because there is high genetic variability in the unselected seeds (PAULA et al., 1997).

An alternative to solving problems arising from rootstocks from seeds is the vegetative propagation method for cutting. This method dispenses the great demand for seeds without genetic variability, making possible the standardization of the rootstocks obtained and, consequently, of the entire production stand. However, the rubber tree is a species that presents difficulties in rooting from cuttings or mini-cuttings, with an extremely low survival rate by vegetative propagation (MEDRADO; APPEZATO-DAGLORIA; COSTA, 1995). The use of some practices, such as the use of preconditioners and plant growth regulators can improve the rooting of the cuttings.

The formation of adventitious roots is due to the interaction of existing factors in the tissues and the translocation of synthesized substances in the developing leaves and buds. Among these factors, growth regulators and nutrients have fundamental importance (MEDRADO; APPEZATO-DAGLORIA; COSTA, 1995; REZENDE; ZUFFELLATO-RIBAS; KOEHLER, 2013). The rooting in rubber tree with the exogenous application of nutrients (MARTÍNEZ-ALONSO et 
al., 2012), or application of synthetic auxins (BLAKESLEY; WESTON; HALL, 1991) has attributed to the polar transport of reserves and auxins closer to the cut region of the cuttings (COSTA et al., 2013). The preconditioning of cuttings in solutions containing nutrients such as nitrogen $(\mathrm{N})$, zinc $(\mathrm{Zn})$, boron $(\mathrm{B})$ and synthetic auxins can improve the percentage, speed, and quality of rooting of the cuttings. However, the recommended concentrations range according to species (TAIZ et al., 2017), the maturity stage of the cuttings, the environmental conditions, and the application (GOULART; XAVIER; DIAS, 2011; HARTMANN et al., 2017).

The nutritional status of a plant has a direct influence on its morphophysiological behavior. $\mathrm{Zn}$ is an essential micronutrient required for the synthesis of tryptophan, a precursor of indoleacetic acid (IAA), which is a growth regulator involved in the formation of adventitious roots (BLAKESLEY; WESTON; HALL, 1991; MENGEL; KIRKBY, 2001). However, despite its proven effects on formation of adventitious roots, little attention has been paid to its possible use as an essential co-factor in the rooting process and being able even replace the use of synthetic auxins. This study aimed to evaluate the effect of the pre-conditioning of rubber tree mini-cuttings in solutions with different zinc concentrations in the improvement of the rootstocks rooting.

\section{MATERIAL AND METHODS}

\section{Plant material and location of the experiment}

The experiment was run in the Plant Propagation Laboratory of Mato Grosso do Sul State University, from June to August of 2015. The softwood mini-cuttings were obtained from rubber tree plants were four months old, cultivar RIM600. The clonal garden was composed of 60 plants, grown in nurseries, on seedbeds of soil. Fungicide was sprayed once on plants to prevent disease. The mini-cuttings were removed below a node, leaving from 1 to 2 pairs of leaves cut in half $(50 \%$ of the leaf area, to reduce evapotranspiration and stimulate rooting) and standardized with $45 \mathrm{~mm}$ length. The mini-cuttings were sterilized with thiophanatemethyl and fungicide.

\section{Experimental design}

The experimental design was randomized blocks with six treatments and four replicates of 10 rubber tree mini-cuttings. The treatments were composed of six solutions with different concentrations of zinc $(0.00,0.04,0.08,0.16,0.32$ and $0.64 \mathrm{mg} \mathrm{L}^{-1}$ of $\mathrm{Zn}$ ) used for immersion of the base of the mini-cuttings of the Rubber tree. The source of zinc used was the chelated form due to better absorption by the cell membranes (MALAVOLTA, 2006), with $20.1 \%$ of $\mathrm{Zn}$ content. The base of mini-cuttings was immersed in the $\mathrm{Zn}$ solutions for 24 hours at room temperature (22-25 $\left.{ }^{\circ} \mathrm{C}\right)$.

\section{Experiment implantation and development}

After immersion, the bottom of the rubber tree mini-cuttings was buried $20 \mathrm{~mm}$ deep in the substrate, in the upright position, in plastic trays containing vermiculite as substrate. Subsequently, the trays were placed in a fitotron-type growth chamber at $25{ }^{\circ} \mathrm{C}$, with 12-hour photoperiod, 5,000 $\mathrm{K}$ intensity, and $95 \%$ of relative air humidity for 60 days. Irrigation was performed daily according to the need of the crop.

\section{Evaluations}

At 60 days after the study implantation, the survival rate, the number of buds, the percentage of mini-cuttings that had leaf abscission, the percentage of mini-cuttings with callogenesis in the root meristem., the percentage of rooted minicuttings, the number of primary roots and root length were evaluated.

\section{Statistical analysis}

The data were submitted to analysis of variance (ANOVA), and, when a significant effect was detected, it was used in the regression analysis for $\mathrm{Zn}$ concentrations.

\section{RESULTS AND DISCUSSION}

The $\mathrm{Zn}$ concentrations significantly influenced the survival rate (Figure 1a), the number of buds (Figure 1b), the percentage of mini-cuttings that had leaf abscission (Figure 1c) and the number of primary roots (Figure 1d) of the rubber tree.

For survival rate (Figure 1a) and the number of buds (Figure 1b) of the rubber tree, the results were adjusted to the quadratic regression model. Pre-conditioning of rubber mini-cuttings at low concentrations of $\mathrm{Zn}$ increased the survival rate (Figure 1a), and the highest survival rate $(61.4 \%)$ was estimated at the concentration of $0.20 \mathrm{mg} \mathrm{L}^{-1}$ of $\mathrm{Zn}$. The maximum number of buds $(10.93$ buds mini-cutting ${ }^{-1}$ ) was estimated at the concentration of $0.16 \mathrm{mg} \mathrm{L}^{-1}$ of $\mathrm{Zn}$ (Figure 1b). These results differ from those reported by Nicoloso, Lazzari and Fortunato (1999), which evaluated the applications of zinc sulfate and zinc chloride $(0,2.5,5.0,10.0$, 
20.0 and $40.0 \mathrm{mg} \mathrm{L}^{-1} \mathrm{Zn}$ ), in cuttings of Platanus acerifolia. The authors showed that the $\mathrm{Zn}$ application by two different sources did not significantly influence the growth of length and number of primary roots, root dry mass, and percentage of rooted cuttings.
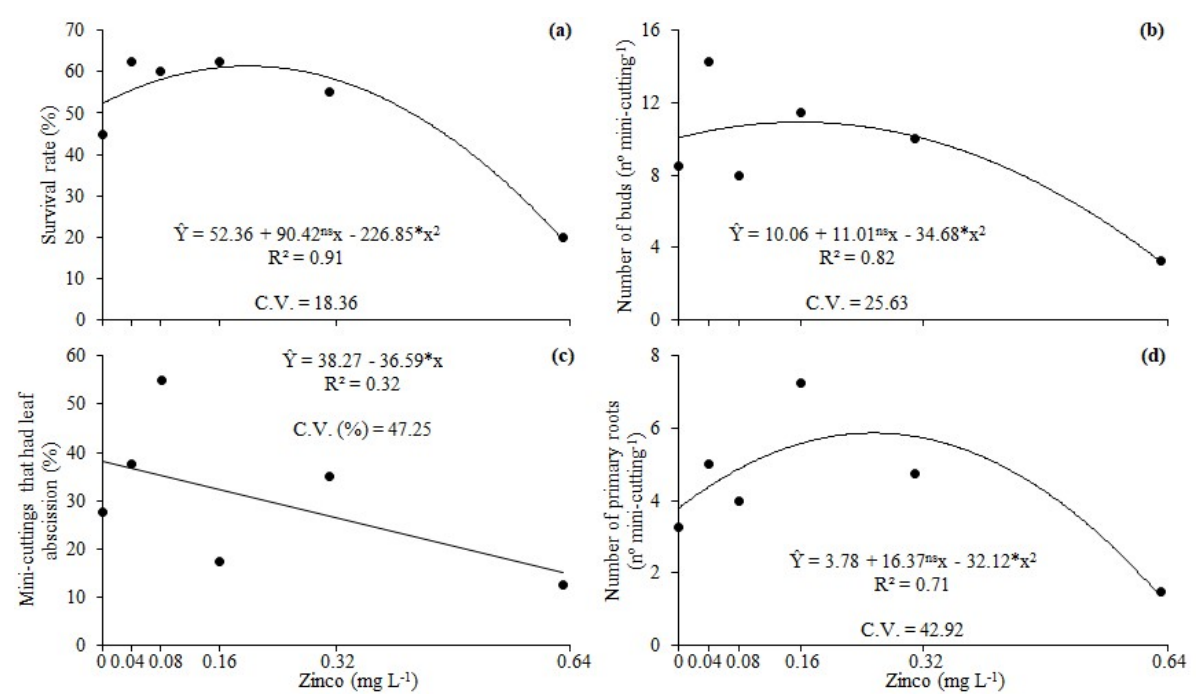

Figure 1. Effect of the pre-conditioning of rubber tree rootstocks mini-cuttings in concentrations of zinc on the survival rate (a), the number of buds (b), the percentage of mini-cuttings that had leaf abscission (c) and the number of primary roots (d) after 60 days.

The mini-cuttings immersed in the concentration of $0.64 \mathrm{mg} \mathrm{L}^{-1}$ of $\mathrm{Zn}$ presented lower survival rate and the number of buds, probably due the phytotoxicity caused by the $\mathrm{Zn}$ excess. According to Long et al. (2003), concentrations of $\mathrm{Zn}$ higher than $0.40 \mathrm{mg} \mathrm{\textrm {L } ^ { - 1 }}$ cause plant phytotoxicity. The survival rate is high due to environmental conditions (such as luminosity, humidity, and temperature) being adequately controlled to guarantee the survival of the propagules until the rooting induction (WENDLING; XAVIER, 2005). In environmental conditions non-controlled, like at nurseries or greenhouses, usually, the survival rate is lower than in this experiment.

The increase in the number of buds with $\mathrm{Zn}$ application (Figure 1b) may be related to the increase of auxin (MENGEL; KIRKBY, 2001). Auxin is responsible for promoting the growth of coleoptile sections, also, it is the hormone responsible for the orderly growth of plants (TAIZ et al., 2017). The higher absorption of $\mathrm{Zn}$ made this element part of systems enzymatic, regulating the metabolism of carbohydrates, phosphates, and proteins in addition to the formation of Auxins, RNA and ribosomes, crucial factors in the regulation of plant growth (HAFEEZ; KHANIF; SALEEM, 2013).

The increase of $\mathrm{Zn}$ concentrations decreases the percentage of mini-cuttings that had leaf abscission (Fig 1c). These results may be related to the ethylene levels in the rubber tree mini-cuttings. 1-Aminocyclopropane-1-carboxylic acid (ACC) plays an essential role in the biosynthesis of the plant hormone ethylene (HOGSETT; RABA; TINGEY, 1981). In a study by Gora and Clijsters (1989), they observed that high $\mathrm{Zn}$ concentration (400 $\mathrm{mg} \mathrm{L}^{-1}$ ) inhibited the synthesis of ACCdependent ethylene in bean plants. The increase in ethylene levels can trigger a range of transformations in the plants, which are related to the expression of genes linked to biotic and abiotic stress and maturation (LI et al., 2013; SIVAKUMAR; WALL, 2013). The respiration, which can accompany the emission of ethylene, increases rapidly during leaf falls (OLIVEIRA; VITÓRIA, 2011). The increase of respiration results in higher spend of reserves and energy. The reserves and energy necessary for the rooting process are spend in the respiration process. Consequently, the rooting process is negatively affected.

The maximum number of primary roots $(5.8$ roots mini-cutting ${ }^{-1}$ ) was observed with $0.25 \mathrm{mg} \mathrm{L}^{-1}$ of $\mathrm{Zn}$ (Figure 1d). These results are different from those reported by Kersten, Lucchesi and Gutierrez (1993), who, when evaluating the effect of $\mathrm{Zn}$ applied to the soil, on plum tree cutting, which collected in the four seasons of the year, found that the percentage of rooting in March was lower in the cuttings treated with Zn. In December and February, the plots of plum treated with $\mathrm{Zn}$ did not differ from those not treated. 


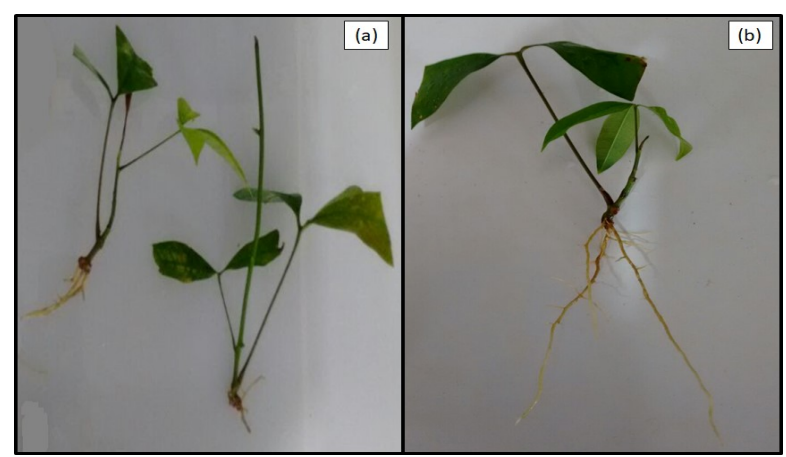

Figure 2. Rubber tree rootstocks mini-cuttings at 60 days after pre-conditioning in concentrations without $\mathrm{Zn}$ (a) and with $0.16 \mathrm{mg} \mathrm{L}^{-1}$ of $\mathrm{Zn}(\mathrm{b})$.

Nicoloso, Lazzari and Fortunato (1999) found that the number of roots and length of the adventitious roots of Salix humboldtidiana cuttings treated with $\mathrm{Zn}$ reduced linearly until the concentration of $200 \mathrm{mg} \mathrm{L}^{-1}$. These differences observed among the species may be related to the concentration and form of $\mathrm{Zn}$ applied in the experiments. According to Malavolta (2006), the best form of absorption of $\mathrm{Zn}$ by the roots of the plants would be in the chelated form. According to Taiz et al. (2017), the uptake of $\mathrm{Zn}$ by the roots and leaves of plants can be influenced by the other components present in the $\mathrm{Zn}$ sources. The $\mathrm{Zn}$ bound to organic compounds facilitated the absorption carried out by the vegetable.

The formation of callogenesis in the root meristem was linearly reduced with the application of $\mathrm{Zn}$ (Figure 3a). Fachinello et al. (1994) reported that the callus appeared after the cutting was cut, when a lesion occurs in the tissues of the xylem and phloem, resulting in the formation of a healing tissue composed of a mass of disorganized parenchymal cells and in different stages of lignification. Some authors consider the formation of callus and roots as entirely independent processes. However, Hartmann et al. (2017) stated that often the roots appear after callus formation, through the differentiation of parenchymal cells. If callus formation precedes the formation and release of adventitious roots, this process is also intricately linked to hormonal and physiological factors of the plant, and for this factor, $\mathrm{Zn}$ is an essential nutrient. Up to $0.25 \mathrm{mg} \mathrm{L}^{-1} \mathrm{Zn}$ concentration, the reduction of callogenesis in the root meristem is attributed to the increase of primary root emission since callus precedes root formation. Above the concentration of $0.25 \mathrm{mg} \mathrm{L}^{-1}$, excess $\mathrm{Zn}$ begins to impair the of callogenesis in the root meristem and hence root formation.

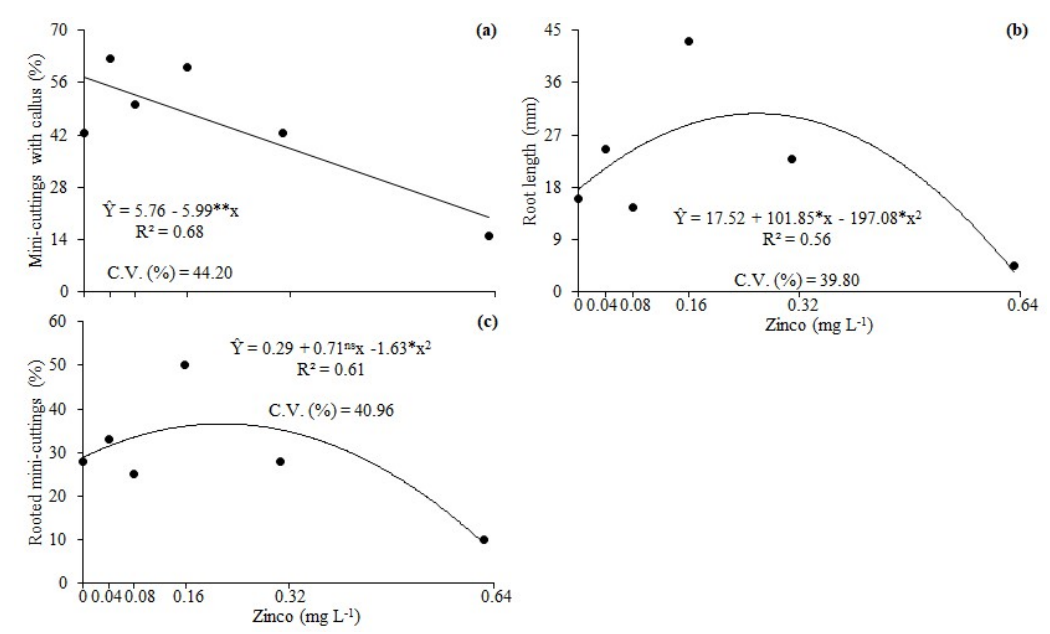

Figure 3. Effect of the pre-conditioning of rubber tree rootstocks mini-cuttings in concentrations of zinc on the percentage of mini-cuttings with callogenesis in the root meristem (a), root length (b) and the percentage of rooted mini-cuttings (c) after 60 days.

The highest mean root length $(30.8 \mathrm{~mm})$ was verified at $0.26 \mathrm{mg} \mathrm{L}^{-1}$ of $\mathrm{Zn}$ (Figure $3 \mathrm{~b}$ ). It is found that low concentrations of $\mathrm{Zn}$ optimized root apex growth. The formation of adventitious roots influenced by the interaction of existing factors in the tissues and the translocation of synthesized 
substances in the developing leaves and buds. Zinc is required in the synthesis of tryptophan, which is a precursor of indoleacetic acid, a phytohormone that participates in the formation of adventitious roots (MENGEL; KIRKBY, 2001; BLAKESLEY; WESTON; HALL, 1991). Taiz et al. (2017) explain that the root apices are much more susceptible to phytohormones than apical buds, so some units of the substance would be able to stimulate rooting.

The percentage of rooted mini-cuttings was influenced by the application of $\mathrm{Zn}$ (Figure 3c). The highest percentage of rooted mini-cuttings was obtained with a concentration of $0.21 \mathrm{mg} \mathrm{L}^{-1}$ of $\mathrm{Zn}$. Several factors may be involved in the rooting process. Also, rubber tree cuttings are difficult to root (BREAKBANE, 1961). Some studies have reported that the production of rooted cuttings of rubber tree clones was not feasible (MUZIK, 1953; MENDES, 1959), only the study by Tynley and Garner (1960) states otherwise. Zn influences the hormonal activity of the plant inducing the formation of calluses and later the adventitious root emission. $\mathrm{Zn}$ is crucial for the synthesis of tryptophan, a precursor of indoleacetic acid-IAA, inhibiting RNAase, activates carbonic anhydrase, and among several other functions already mentioned, participates in the structure of superoxide dismutase. Since IAA is a phytohormone responsible for cell growth, as well as an adventitious root inducer, carbonic anhydrase is a catalyst for the formation of carbonic acid, whose element participates in the neutralization of cellular pH (DECHEN; HAAG; CARMELLO, 1991; AMBERGER, 1996).

\section{CONCLUSIONS}

With the concentrations from 0.16 to 0.26 $\mathrm{mg} \mathrm{L}^{-1}$ of $\mathrm{Zn}$, the highest values of survival rate, the number of buds, the number of primary roots, callogenesis in the root meristem, root length and percentage of rooted mini-cuttings were observed. The use of zinc in the rubber tree mini-cuttings linearly reduces the number of leaves that had abscission and the formation of callogenesis in the root meristem.

\section{ACKNOWLEDGEMENTS}

We would thanks to the Foundation for Support to the Development of Education, Science and Technology of the State of Mato Grosso do Sul - FUNDECT, by the financial support.

RESUMO: A seringueira (Hevea brasiliensis Müell. Arg.) é uma espécie de importância econômica para a indústria da borracha natural do Brasil e do mundo. Esta espécie apresenta recalcitrância ao enraizamento e suas estacas são difíceis de se propagar. Este trabalho objetivou avaliar o efeito do précondicionamento de miniestacas de seringueira com zinco na melhoria do enraizamento adventício de portaenxertos. As miniestacas foram padronizadas com $45 \mathrm{~mm}$ de comprimento e submetidas ao précondicionamento por imersão da miniestaca em soluções contendo $0.00 ; 0,04 ; 0,08 ; 0,16 ; 0,32$ e $0,64 \mathrm{mg} \mathrm{L}^{-1} \mathrm{de}$ $\mathrm{Zn}$, por 24 horas. O delineamento experimental foi em blocos ao acaso, com seis tratamentos e quatro repetições de 10 miniestacas. As miniestacas de seringueira foram colocadas em câmara de crescimento tipo fitotron, a $25{ }^{\circ} \mathrm{C}$, com fotoperíodo de 12 horas, intensidade de $5.000 \mathrm{~K}$ e umidade relativa do ar de $95 \%$ por 60 dias. Foram avaliadas a taxa de sobrevivência, o número de gemas, a porcentagem de miniestacas que apresentaram abscisão foliar, o percentual de miniestacas com calogênese no meristema radicular, o percentual de miniestacas enraizadas, o número de raízes primárias e o comprimento das raízes. Os maiores valores de taxa de sobrevivência, o número de gemas, o número de raízes primárias, a porcentagem de miniestacas com calogênese no meristema radicular, o percentual de miniestacas enraizadas e o comprimento radicular foram verificados com 0,16 a $0,26 \mathrm{Mg} \mathrm{L}^{-1}$ de $\mathrm{Zn}$. O uso de zinco nas miniestacas de seringueira reduz linearmente a porcentagem de miniestacas que tiveram abscisão foliar e a formação de calogênese no meristema radicular.

PALAVRAS-CHAVE: Hevea brasiliensis. Miniestaquia. Propagação vegetativa. Clonagem. Indução de enraizamento.

\section{REFERENCES}

ALVARENGA, A. P.; CARMO, A. F. S. Seringueira. 2a Ed. Viçosa: Epamig, 2014. 894 p. 
AMBERGER, A. Pflanzenernährung: ökologische und physiologische grundlagen, dynamik und stoffwechsel der nährelemente. $4^{\mathrm{a}}$ ed. Stuttgart: Eugen Ulmer. 1996. 319 p.

BLAKESLEY, D.; WESTON, G. D.; HALL, J. F. The role of endogenous auxin in root initiation. Part I: Evidence from studies on auxin application, and analysis of endogenous levels. Plant Growth Regulation, v. 10, n. 11, p. 341-353, 1991. https://doi.org/10.1007/BF00024593

BREAKBANE, A. B. Structure of the plant stem in relation to adventitious rooting. Nature, v. 192, n. 12, p. 954-955, 1961. https://doi.org/10.1038/192954a0

COSTA, C. T.; ALMEIDA, M. R.; RUEDELL, C. M.; SCHWAMBACH, J.; MARASCHIN, F. S.; FETTNETO, A. G. When stress and development go hand in hand: main hormonal controls of adventitious rooting in cuttings. Frontiers in Plant Science, v. 4, n. 113, pp.1-19, 2013. https://doi.org/10.3389/fpls.2013.00133

DECHEN, A. R.; HAAG, H. P.; CARMELLO, Q. A. C. Funções dos micronutrientes nas plantas. In: FERREIRA, M. E.; CRUZ, M. C. P. (Eds.). Micronutrientes na agricultura. Piracicaba: Potafos, p. 65-78, 1991.

FACHINELlO, J. C.; HOFFMANN, A.; NACHTIGAL, J. C.; KERSTEN, E.; FORTES, G. R. L. Propagação de plantas frutíferas de clima temperado. $1^{\mathrm{a}}$ ed. Pelotas: UFPEL. 1994. 178 p.

GONÇALVES, P. S.; MARTINS, A. L. M.; FURTADO, E. L.; SAMBUGARO, R.; OTTATI, E. L.; ORTOLANI, A. A.; GODOY-JÚNIOR, G. Desempenho de clones de seringueira da série IAC 300 na região do planalto de São Paulo. Pesquisa Agropecuária Brasileira, v. 37, n. 2, p.131-138, 2002.

https://doi.org/10.1590/S0100-204X2002000200003

GORA, L.; CLIJSTERS, H. Effect of copper and zinc on the ethylene metabolism in Phaseolus vulgaris L. In: CLIJSTERS, H., et al. (Ed.). Biochemical and physiological aspects of ethylene production in lower and higher plants. Dordrecht: Springer, p. 219-228, 1989.

GOULART, P. B.; XAVIER, A.; DIAS, J. M. M. Efeito dos cofatores hidroquinona, prolina e triptofano no enraizamento de miniestacas de clones de Eucaliptus grandis $x$ E. urophylla. Revista Árvore, v. 35, n. 5, p. 1017-1026, 2011. http://dx.doi.org/10.1590/S0100-67622011000600007

HAFEEZ, B.; KHANIF, Y. M.; SALEEM, M. Role of zinc in plant nutrition - A Review. American Journal of Experimental Agriculture, v. 3, n. 2, p. 374-391, 2013. https://doi.org/10.9734/AJEA/2013/2746

HARTMANN, H. T.; KESTER, D.; DAVIES-JUNIOR, F.; GENEVE, R.; WILSON, S. Hartmann \& Kester's Plant propagation: principles and practices. $9^{\text {th }}$ ed. Boston: Pearson, 2017. $1024 \mathrm{p}$.

HOGSETT, W. E.; RABA, R. M.; TINGEY, D. T. Biosynthesis of stress ethylene in soybean seedlings: Similarities to endogenous ethylene biosynthesis. Physiologia Plantarum, v. 53, n. 3, p. 307-314, 1981. https://doi.org/10.1111/j.1399-3054.1981.tb04505.x

KERSTEN, E.; LUCCHESI, A. A.; GUTIERREZ, L. E. Efeito do ácido indolbutírico no enraizamento de estacas de ramos de plantas de ameixeira (Prunus salicina, Lindl.). Scientia Agricola, v. 50, n 1, p. 19-26, 1993. http://dx.doi.org/10.1590/S0103-90161993000100004

LI, X.; ZHU, X.; MAO, J.; ZOU, Y.; FU, D.; CHEN, W.; LU, W. Isolation and characterization of ethylene response factor family genes during development, ethylene regulation and stress treatments in papaya fruit.

Plant Physiology and Biochemist, v. 70, n. 9, p. 81-92, 2013. https://doi.org/10.1016/j.plaphy.2013.05.020

LONG, X. X.; YANG, X. E.; NI, W. Z.; YE, Z. Q.; HE, Z. L.; CALVERT, D. V.; STOFFELLA, J. P. Assessing zinc thresholds for phytotoxicity and potential dietary toxicity in selected vegetable crops. 
Communications in Soil Science and Plant Analysis, v. 34, n. 9, p. 1421-1434, 2003.

https://doi.org/10.1081/CSS-120020454

MALAVOLTA, E. Manual de nutrição de plantas. $1^{\mathrm{a}}$ ed. São Paulo: Agronômica Ceres, 2006. 631 p.

MARTÍNEZ-ALONSO, C.; KIDELMAN, A.; FEITO, I.; VELASCO, T.; ALÍA, R.; GASPAR, M. J.; MAJADA, J. Optimization of seasonality and mother plant nutrition for Pinus pinaster Ait. New Forests, v. 43, n. 9, p. 651-663, 2012. https://doi.org/10.1007/s11056-012-9333-9

MARTINS, A. L. M.; RAMOS, N. P.; GONCALVES, P. S.; VAL, K. S. Influência de porta-enxertos no crescimento de clones de seringueira no estado de São Paulo. Pesquisa Agropecuária Brasileira, v. 35, n. 9, p. 1743-1750, 2000. https://doi.org/10.1590/S0100-204X2000000900006

MEDRADO, M. J. S.; APPEZATO-DA-GLORIA, B.; COSTA, J. D. Alterações anatômicas em estacas de seringueira (Hevea brasiliensis clone RRIM 600) em resposta a diferentes técnicas de indução ao enraizamento. Scientia Agricola, v. 52, n. 1, pp. 89-95, 1995. https://doi.org/10.1590/S0103-90161995000100016

MENDES, L. O. T. A multiplicação da seringueira (Hevea brasiliensis Muell. Arg.) por meio de estacas. Bragantia, v. 18, n. 11, p. 245-274, 1959. https://doi.org/10.1590/S0006-87051959000100017

MENGEL, K.; KIRKBY, E. A. Principles of plant nutrition. $5^{\text {th }}$ ed. Heidelberg: Springer Netherlands, 2001. $849 \mathrm{p}$.

MUZIK, T. J. Growth and renegeration in Hevea seedlings. Science, v. 117, n. 3047, p. 555-556, 1953. https://doi.org/10.1126/science.117.3047.555

NICOLOSO, F. T.; LAZZARI, M.; FORTUNATO, R. P. Propagação vegetativa de Platanus acerifolia Ait.: (i) efeito de tipos fisiológicos das estacas e épocas de coleta no enraizamento de estacas. Ciência Rural, v. 29, n. 3, p. 479-485, 1999. https://doi.org/10.1590/S0103-84781999000300017

OLIVEIRA, J. G.; VITORIA, A. P. Papaya: nutritional and pharmacological characterization, and quality loss due to physiological disorders. An overview. Food Research International, v. 44, n. 5, p. 1306-1313, 2011.: https://doi.org/10.1016/j.foodres.2010.12.035

PAULA, N. F.; BORGES, E. E. L.; BORGES, R. C. G.; PAULA, R. C. Alterações fisiológicas em sementes de seringueira (Hevea brasiliensis Muell. Arg.) durante o armazenamento. Revista Brasileira de Sementes, v. 19, n. 2, p. 327-334, 1997. https://doi.org/10.17801/0101-3122/rbs.v19n2p326-333

REZENDE, F. P. F.; ZUFFELLATO-RIBAS, K. C.; KOEHLER, H. S. Aplicação de extratos de folhas e tubérculos de Cyperus rotundus L. e de auxinas sintéticas na estaquia caulinar de Duranta repens L. Revista Brasileira de Plantas Medicinais, v. 15, n. 4, p. 639-645, 2013. https://doi.org/10.1590/S151605722013000500003

SIVAKUMAR, D.; WALL, M. M. Papaya fruit quality management during the postharvest supply chain. Food Reviews International, v. 29, n. 1, p. 24-48, 2013. https://doi.org/10.1080/87559129.2012.692138

TAIZ, L.; ZEIGER, E.; MØLLER, I. M.; MURPHY, A. Plant physiology and development, $6^{\text {th }}$ ed. Sunderland: Sinauer Associates. 2017. 761 p.

TYNLEY, G. M.; GARNER, R. J. Developments in the propagation of clones of Hevea brasiliensis by cuttings. Nature, v. 186, n. 4722, p. 407-408, 1960. https://doi.org/10.1038/186407a0

WENDLING, I.; XAVIER, A. Influência do ácido indolbutírico e da miniestaquia seriada no enraizamento e vigor de miniestacas de clones de Eucalyptus grandis. Revista Árvore, v. 29, n. 6, p. 921-930, 2005. http://dx.doi.org/10.1590/S0100-67622005000600011 